\title{
Analysis of Effect of Foreign Direct Investment, Debt to the IMF and Stock Values Against Economic Growth in Developing Countries Members of the Organization of Islamic Cooperation (OIC)
}

Dwi Susilowati, Muhammad Khoirul Fuddin, Risky Angga Pramuja, Firdlha Aksari Anindyntha, and Novi Primitasari

University of Muhammadiyah Malang

\section{Abstract}

The economic growth of Islamic countries in the last decade has a significant economic growth trend. One of the causes of the increasing economic growth of the Islamic State of the OIC is the increasing flow of foreign capital into developing Islamic

Corresponding Author:

Dwi Susilowati

dwi_s@umm.ac.id

Received: 10 February 2019

Accepted: 14 March 2019

Published: 28 March 2019

Publishing services provided by Knowledge E

(c) Dwi Susilowati et al. This article is distributed under the terms of the Creative Commons Attribution License, which permits unrestricted use and redistribution provided that the original author and source are credited.

Selection and Peer-review under the responsibility of the ICIEBP Conference Committee.

\section{S OPEN ACCESS} countries, which has an impact on the rapid growth of infrastructure in the country concerned. Debt to the IMF is also an alternative for the country to get cash injections, this is also done by developing Islamic countries of OIC members to get cash injections to increase economic growth. Stock trading is also one of the key factors of economic activity in various countries, including the developing Islamic countries of the OIC member. The purpose of this study is to see how much influence foreign direct investment, debt to IMF and share value on economic growth in the Islamic developing countries of OIC members. The analytical tool used in this study is panel data regression with a fixed effect model. As a result, foreign direct investment and stock value have a significant positive effect on economic growth, while debt to the IMF has a significant negative effect on economic growth.

Keywords: Foreign Direct Investment, Debt to the IMF, Stock Values, Economic Growth, Organization of Islamic Cooperation (OIC)

\section{Introduction}

Economic growth in OIC member countries in the last few decades has experienced a significant trend, especially for OIC member countries with the status of developing countries. One of the positive trends in economic growth in developing OIC countries is due to the increasingly open international economic relations, both among OIC members and not OIC countries. 
The reinforcement of economic conditions in some developing countries of the OIC which is reflected in the increase in economic growth that expected to reduce the dependence of Islamic countries on western countries in solving problems among the member of OIC countries and strengthen the economic integration among OIC members.

Indonesia is one of the OIC member countries which has a large rate of economic growth in Southeast Asia and one of the countries that has the largest Muslim population in the world. Turkey is a developing country located in Asia and Europe where it has a majority Muslim population with a high level of economic growth. Significant economic growth, one of which comes from trading activities on the stock exchange and foreign investment. Malaysia is a Muslim country in Southeast Asia which has the third largest economic growth rate and stock trading activities that are quite high in the ASEAN region. Pakistan is a Muslim country in the South Asian region with a majority of Muslim population and the next eleven country which has a rapid rate of economic growth in the 21 st century.

There are three important variables that become trigger for the developing countries of the OIC in increasing rate of economic growth so it will create competencies that be able to compete with developed countries. The three elements include foreign direct investment, debt to the IMF and trading activities on the stock exchange. These three activities certainly cannot be separated from international economic activities carried out both with developed countries, developing even poor countries.

Foreign Direct Investment (FDI) can be defined as a form of inter-company cooperation involving significant equity shares or effective management that is usually carried out between different countries (L. Erdal \& Göçer, 2015). FDI also has an effect on production, employment, income, prices, exports, imports, economic growth, balance of payments, and general welfare that can be observed in the host country. (F. Erdal \& Tatoglu, 1999). The foreign direct investment contribution for developing countries in OIC cannot be considered one eye because with the arrival of incoming investments that can be utilized as best as possible, it will have an effective impact on all sectors of the economy in the country concerned.

One of the financing of other economic growth which is a trend among countries is by borrowing funds, one of which is to the IMF. Debt carried out by various countries, especially developing countries, has a significant positive influence on the level of growth, even the effects of debt in the long term can also increase public investment and productivity of a country (Checherita \& Rother, 2010). The use of debt for developing 
countries is usually also used to finance the state expenditure deficit (Kharusi \& Ada, 2018).

The value of shares and all activities on the trading floor have an influence on the world economic movement. The majority of the OIC member countries are countries that adhere to the open economy and have companies that go public, of course, will be related to the activities of the stock market. The more active activities on the stock market will increase the level of economic growth of a country (Masoud, 2013).

This research will attempt to examine the role of the direct investment impact that flows to several developing OIC member countries, the debt given by the IMF to several developing countries of OIC members, and the value of shares in developing OIC member countries, whether they have an influence on the level economic growth in each developing member country of the OIC because the three types of independent variables used cause capital inflows that can have an impact on economic growth.

\section{Literature Review}

\subsection{Organization of islamic cooperation (OIC)}

The Organization of the OIC is a multi-lateral organization between state and government, which until now has 57 members states and has been internationally recognized as a "Muslim world" institution. The OIC is the second largest world organization with the UN, OIC member countries include the Asian continent as many as 28 countries, 26 African countries, 2 South America country and 1 Europe countries are the countries of the Muslim population. OKI was established in 1969 as an Islamic conference organization but in 2011 there was a change in the official name and logo initiated by the government of Saudi Arabia, through the Islamic Summit in Rabat, Morocco. The main objective of the OIC which is stated in the OIC Charter is to make the entire Muslim community of the world unite into the same body so as to strengthen the solidarity and cooperation of the world Muslim community, through political, economic and social activities.

\section{Foreign Direct Investment}

Investment is a form of investment made by domestic and foreign investors. Foreign parties who invest capital can be divided into two forms, namely direct investment and indirect investment (Jhingan, ML, 2004). Direct investment is an investment from a 
foreign company on the facto or the jure to supervise assets (assets) invested in capital importing countries through investment (Machmud, 2016).

In the short-term foreign direct investment a right impact on the real economy growth with the condition that investors have complete knowledge about investment, on the contrary when foreign direct investment is carried out by investors who are not very clear about the investment climate it is less able to increase economic growth and financial markets (Gajdka \& Pietraszewski, 2016)

\subsection{Debt to the IMF}

In various studies say the debt has different effects to different countries, in the case of some countries debt has positive effect when it is used as productive activities but the debt would have a negative impact when it is used for consumptive activities. Whereas when viewed from the short and long term, in the short term the debt will have a positive impact to increase the acceleration of economic growth, but in the long run debt can have a negative impact if the debt repayment has a high interest rate.

The relationship between economic growth and foreign debt services for Turkey for the period 1956-1996 using multivariate co-integration techniques. This study shows the negative relationship between foreign debt and economic growth in the long term. Foreign debt causes the country's economic growth to decline due to the high debt and total interest paid (Karagöl, 2002)

\subsection{Share value}

The value and price of shares listed on the stock exchange will affect the economic growth of a country, but it can also predict the stock value of a country's economic growth in the future be some ayear. The share value affects the country's economic growth through activities in the financial sector both in the short term and long term (Faisal, Muhammad, Tursoy, 2016)

The stock market has played a significant role in the developed economies and developing markets. The stock market which has high market volatility has a negative and insignificant influence correlated with real GDP per capita. The terms of the stock value play a positive role in economic growth when stock movements do not fluctuate or have a negative trend (Masoud, 2013).

There is a positive relationship between the stock market and economic conditions because the higher value of stock trading in the stock market can stimulate investment 
activity (Gajdka \& Pietraszewski, 2016). The higher country's investment activity will increases the national income so it has positive implications for economic growth.

\section{Methodology}

This study wants to see the impact of Foreign Direct Investment (FDI), IMF debt, and stock value on economic growth (GDP) in several developing OIC member countries. The method for regression analysis uses panel data because it consists of a combination of cross section data from four developing countries of the OIC members (Indonesia, Malaysia, Pakistan and Turkey) and time series data from 1999-2016. The analysis technique in the panel data consists of three, namely Pooled OLS Model, Fixed Effect Model (FEM) and Random Effect Model (REM). Furthermore, from the three models, a test is conducted to determine which model is appropriate. Tests that can be done are Chow Test, Hausman Test, and LM Test. Chow test to determine which model is better used between Pooled OLS Model and Fixed Effect Model. Furthermore, the LM test is to choose between Pooled OLS Model and Random Effect Model. The last test is the Hausman test to choose between Fixed Effect Model and Random Effect Model (Gujarati, 2012). Based on the results of the test, a good model used in this study is Fixed Effect Model with the regression equation as follows:

$$
Y_{i t}=\beta_{0}+\beta_{1} X_{1 i t}+\beta_{2} X_{2 i t}+\beta_{3} X_{3 i t}++\mu_{i t}
$$

Where $Y$ is GDP, $\beta_{0}$ is a constant, $\beta_{1}, \beta_{2}, \beta_{3}$, are regression coefficients, $X_{1}$ is FDI, $X_{2}$ is IMF to debt, $X_{3}$ is stock value, and $\mu$ is error term.

\section{Result}

Economic growth of a country can be described through GDP where the higher the GDP of a country, the better economic conditions of the country. In some developing country members of the OIC which became the object of study, has a GDP that is increasing every year. Every poor, developing and advanced country will certainly try to increase GDP so that its economy does not stagnate and become better from year to year. 


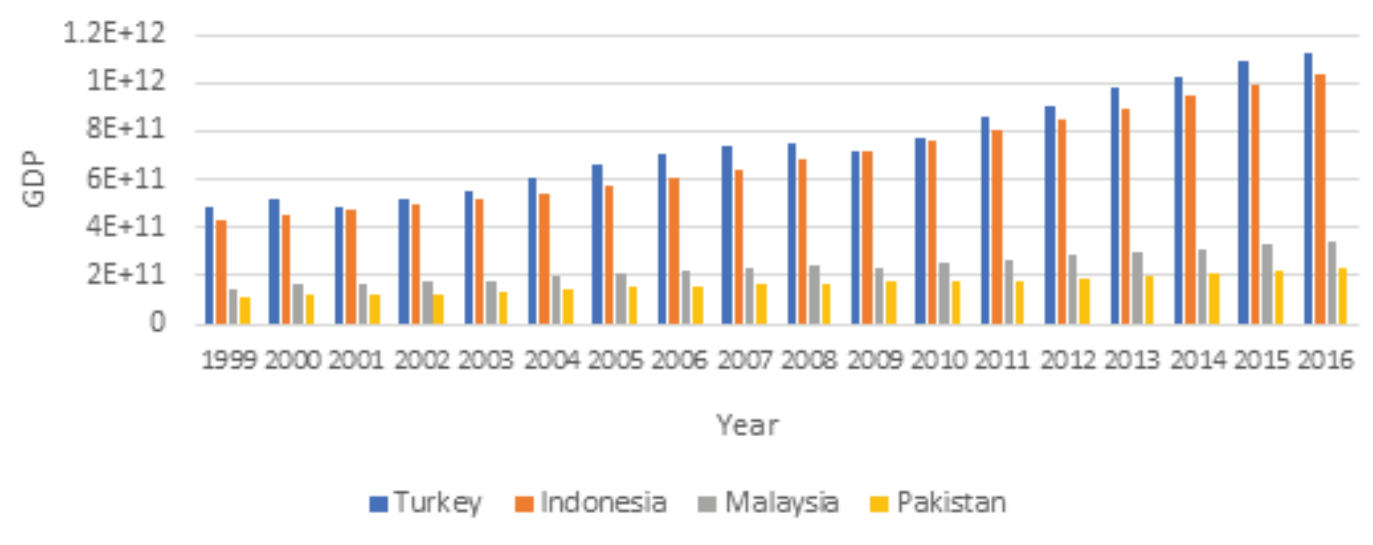

Figure 1: GDP of Four Developing Countries OIC Members.

In Figure 1, it has been seen that for almost two decades, Turkey has the highest GDP than the other three developing OIC member countries, followed by Indonesia, which is ranked second, Malaysia, and the lowest GDP with Pakistan. The differences between GDP Turkey and Indonesia are not very significant every year, but there is a fairly high gap between GDP Turkey and Indonesia with Malaysia and Pakistan.

All countries will establish relationships with other countries one of which is in the form of investment because investment is an important component in supporting economic growth. Developing countries cannot improve their economic conditions if they only rely on relatively small amounts of domestic investment, thus requiring foreign investment.

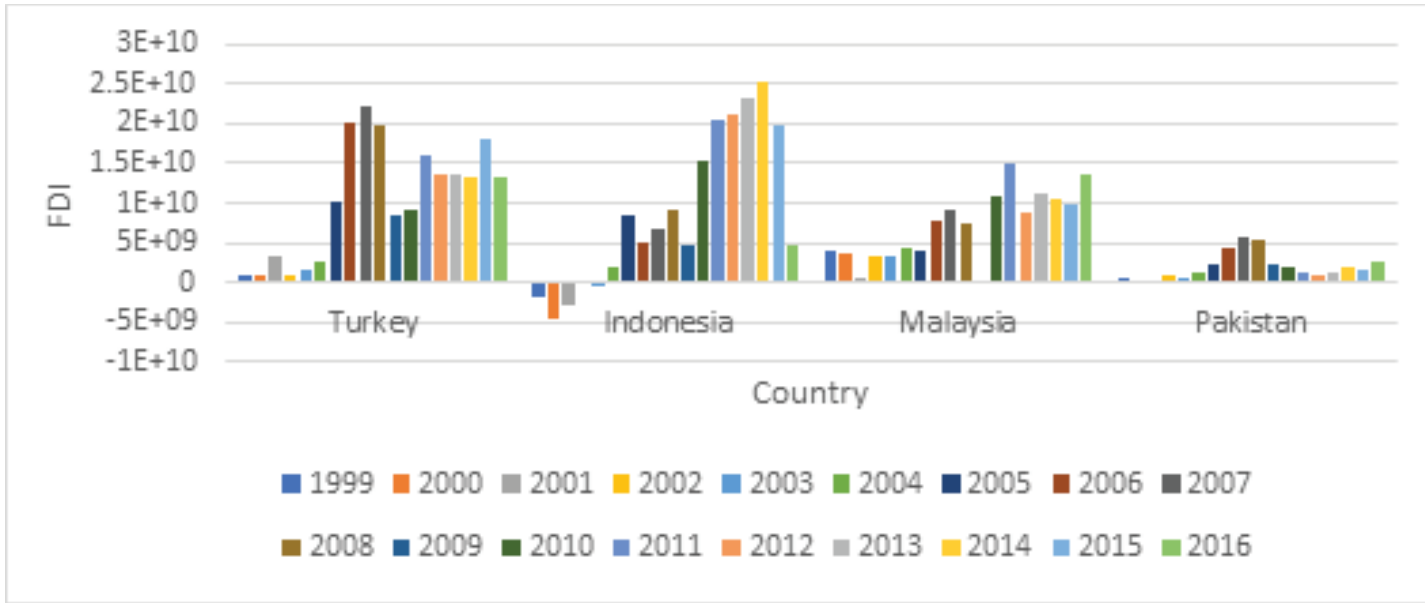

Figure 2: FDI Four Developing Countries OIC Members.

Figure 2 shows the amount of FDI in the last two decades in four developing OIC member countries that tend to fluctuate. Indonesia had experienced minus FDI in 1999 - 2003 after the economic crisis in 1998, thus reducing the confidence of foreign countries to invest in Indonesia. Indonesia FDI started to increase after the post-crisis economic conditions began to return stable, even in the year 2010- 2015 capable of 
winning compared with three other developing country members of the OIC. The State of Pakistan is the country with the smallest FDI because it is a country that is vulnerable to conflict that can affect the stability of economic conditions and reduce the confidence of foreign investors.

As big as a country is doing debt to finance development activities in order to support economic growth. One source of loan funds commonly obtained by the state is funds from the IMF. Debt has a positive impact if it is really used for productive activities which will produce benefits in the future and have a negative impact if used for consumptive activities that actually burden future generations.

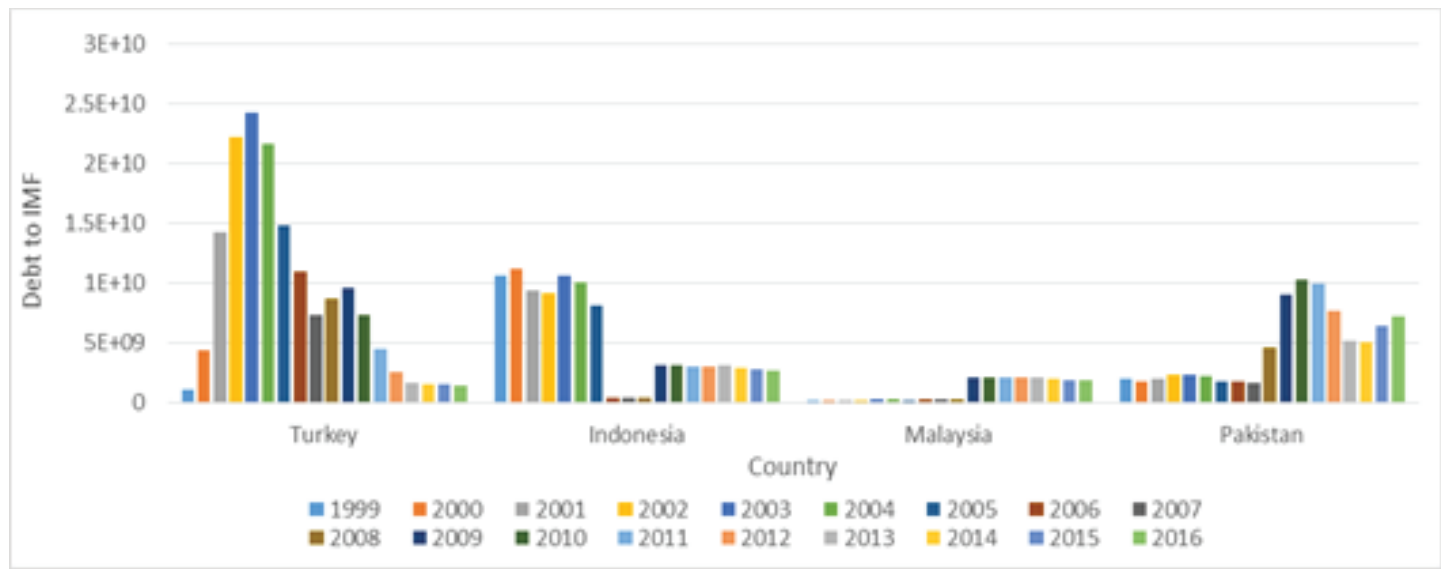

Figure 3: Debt to IMF Four Developing Countries OIC Members.

Turkey is the country that has the highest debt to the IMF and vice versa for the Malaysian country as shown in Figure 3. The high debt to the IMF carried out by Turkey is in line with the high economic growth. Over time, countries whose economic conditions are better than before will try to pay off debts so as not to pay higher interest rates or create new problems if they fail to pay in the future. Therefore, the debt trend tends to decrease as in Turkey and Indonesia. Conversely, countries with small debts will tend to increase debt to finance activities to encourage economic growth, such as Malaysia and Pakistan.

Trade in financial sector in the stock exchange, such as stocks can encourage economic growth other than trade in the real sector which has been widely applied in developed countries. However, at present, developing countries, including OIC members, are also actively participating in the stock trading on the stock exchange, thus expanding the global economic turnover and increasing the value of its stock trading.

In Figure 4 it can be seen that Turkey has the highest stock value and its value is quite lame with the other three OIC member developing countries. This illustrates the number of Turkish companies that have gone public and the frequent intensity of stock 


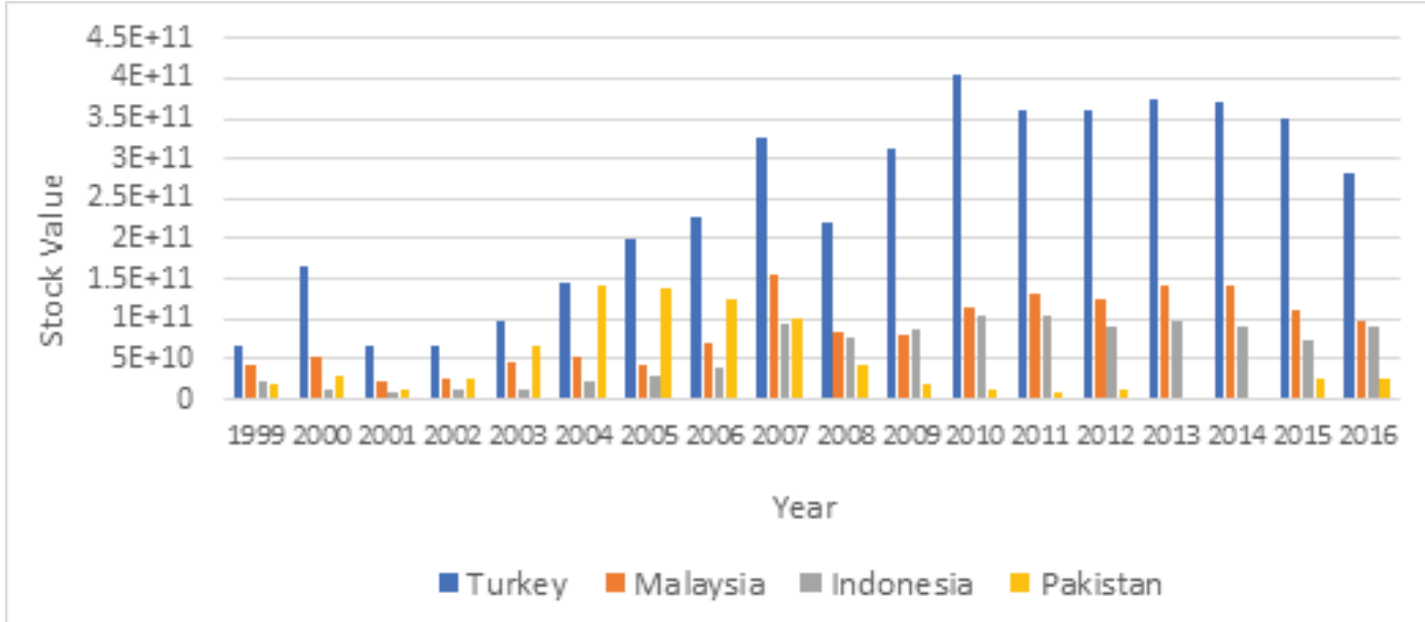

Figure 4: Stock Value Four Developing Countries OIC Members.

trading on the stock exchange. For almost two decades, the country's stock value trends have been positive, while in Pakistan the stock value trend is negative.

\subsection{Analysis results}

The results of the panel data regression analysis equation with Fixed Effect Model are:

$$
Y=3,420+10,844 X_{1}-5,234 X_{2}+0,610 X_{3}+\mu
$$

TABLE 1: Data Panel Estimation Results with Fixed Effect Model (FEM).

\begin{tabular}{|c|c|c|c|c|}
\hline \multicolumn{5}{|c|}{ Dependent Variables: GDP (Y) } \\
\hline Independent Variable & Influence & Coefficient & Prob & Std.Error \\
\hline Constanta & + & 3,420 & $0,000^{*}$ & 3,360 \\
\hline FDI (X1) & + & 10,844 & $0.079^{* *}$ & 2,083 \\
\hline Debt to IMF (X2) & - & $-5,233$ & $0.007^{*}$ & 2,931 \\
\hline Stock Value (X3) & + & 0.610 & $0,000^{*}$ & 0.218 \\
\hline \multicolumn{5}{|c|}{ * Significant in $5 \%,{ }^{* *}$ Significant in $10 \%$} \\
\hline R-square within & \multicolumn{4}{|c|}{0.6353} \\
\hline Prob F & \multicolumn{4}{|c|}{0.0000} \\
\hline
\end{tabular}

The regression coefficient for FDI variable (X1) is 10.844 which means that if there is a 1 unit increase in FDI (X1), then there will be an increase of 10.844 in GDP (Y). The regression coefficient for IMF debt to variable $(X 2)$ is 5.233 which means that if there is a 1 unit increase in the amount of IMF debt $(X 2)$, there will be a decrease of 5.233 
in GDP $(Y)$. Furthermore, the regression coefficient for the stock value variable $(X 3)$ is 0.610 , which means that if there is a 1 unit increase in stock value (X3), there will be an increase of 0.610 in GDP $(Y)$. The results of the panel data regression with Fixed Effects Model (FEM) produce the coefficient of determination $\left(R^{2)}\right.$ equal to $63.53 \%$. This means that the GDP variable can be explained or influenced by FDI variables, IMF debt, and stock value of $63.53 \%$ and the remaining $36.47 \%$ is explained by other variables not included in the model.

Simultaneous statistical test is indicated by the value of prob $\mathrm{F}=0.0000$ or $0 \%$ less than $\alpha=5 \%$, which means that variables FDI, IMF debt, and stock values together affect GDP in the four developing countries of the OIC member. Partial statistical test results are to see how the influence of each independent variable on the dependent variable will be briefly shown in the following table:

TABLE 2: Variable Influence.

\begin{tabular}{l|c|c|}
\hline Independent Variable & $\begin{array}{c}\text { Regression } \\
\text { Results }\end{array}$ & Influence \\
\hline FDI $(X 1)$ & Positive & Significant \\
\hline Debt to IMF $(X 2)$ & Negative & Significant \\
\hline Value Stock $(X 3)$ & Positive & Significant \\
\hline Source: Author, 2018 & & \\
\hline
\end{tabular}

\section{Discussion}

FDI variables have a positive and significant effect of 10.844 on GDP and are the variables that have the most dominant influence on economic growth in some developing countries of the OIC member. The higher the amount of FDI will accelerate the pace of investment and encourage economic growth in developing countries. Foreign investment funds can be used for the development process, increase the country's foreign exchange reserves, as well as the company's expansion as an effort to increase production output which hopes to absorb more workers, thus increasing the income and welfare of the recipient countries. Government policy support related to FDI is needed to create investment opportunities for foreign investors and foster investor confidence to invest in the recipient country.

The existence of FDI can provide concrete benefits, namely an increase in assets and infrastructure, so that it has an impact on economic growth in developing countries such as Pakistan. The results show the positive impact of FDI on economic growth (Gudaro, Chhapra, \& Sheikh, 2010). FDI also has an important impact on a country's economy 
because it contributes to increased production, labor productivity, added value of goods, and an alternative financing of budget deficits (Zoto, 2015).

Debt to IMF is a variable that has a negative and significant effect of 5.233 on GDP, which means an increase in IMF debt to actually reduce economic growth in some developing countries of the OIC member. Basically debt has a positive and negative impact on the country concerned. If debt has a negative impact, it shows the use of debt that tends to consumptive needs rather than productivity, so it is less useful for economic growth stimulus. In addition, countries that have debts will be burdened by payment of debt principal and their relatively high interest.

Impact of domestic debt and foreign debt on economic growth in Pakistan during the period (1980-2010) using the least squares approach based on co-integration testing, unit root and serial correlation. As a result public debt has a negative impact on economic growth (Atique \& Malik, 2012).

The value of shares has a positive and significant influence of 0.610 on GDP which means that the increase in stock value can increase economic growth in some developing OIC member countries. The high value of shares illustrates the activity of stock trading volume on the stock as well. This indirectly indicates an increase in capital for companies in the country concerned. If the company's capital increases, the company will be able to produce more output in the economy so that it has an impact on increasing economic growth.

The development of the stock market which includes the volume of stock trading transactions can affect positive economic growth in the long term in developing countries such as Turkey. Therefore, the country's policy in developing the stock exchange to increase the value of the company's shares in developing countries is very important if it wants to increase economic growth (Pay, Rich, \& Yildirim, 2014).

\section{Conclusion}

Significant economic growth in several developing OIC member countries in recent years has been influenced by an increase in capital flows through foreign investment which has a positive impact on economic growth i. In addition, the volume of stock trading transactions on the exchange increased can accelerate economic growth through the financial sector. Some developing countries including OIC members, they are also indebted to the IMF as an effort to obtain additional funds to support economic activity and encourage economic growth. But the results of the study show that increased debt actually decreases economic growth. 
Based on the results of the research that has been conducted, it showed that developing countries of OIC's members should reduce debt to the IMF if they want to increase economic growth by looking for another funding sources. The alternative is increasing Foreign Direct Investment (FDI) and the volume of stock trading transactions in the stock market which empirically contribute to the economic growth of the OIC countries member. The way to attract foreign investors to countries is by maintenance the economic climate and political stability so it will increase confidence of foreign investors both on real investment in the form of FDI and the financial sector through stock trading.

\section{References}

[1] Atique, R., \& Malik, K. (2012). Impact of domestic and external debt on the economic growth of Pakistan. World Applied Sciences Journal, 20 (1), 120-129.

[2] Pay, Y., Kaya, A., \& Yildirim, M. (2014). Effects of Stock Market Development on Economic Growth: Evidence from Turkey. International Journal of Financial Research, 5 (1), 93-100.

[3] Carkovic, M.V., Levine, R. (2002). Does foreign direct investment accelerate economic growth? University of Minnesota Department of Finance Working Paper.

[4] Checherita, C., \& Rother, P. (2010). Wo rking Pa per S eries The impact of high and growing government debt on the economic growth and empirical investigation for the euro area by Cristina Checherita Working Paper series no 1237 / August 2010 The Impact Of High And Gr, (1237).

[5] Erdal, F., \& Tatoglu, E. (1999). Locational Determinants of Foreign Direct Investment in Turkey: a Time Series Analysis. Opf. Slu.Cz, (August 1999), 322-331

[6] Erdal, L., \& Göçer, i. (2015). The Effects of Foreign Direct Investment on R \& D and Innovations: Panel Data Analysis for Developing Asian Countries. Procedia - Social and Behavioral Sciences, 195, 749-758.

[7] Experience, T. G. (2018). The Effect of Government Debt and Other Determinants on Economic Growth.

[8] Gajdka, J., \& Pietraszewski, P. (2016). Economic Growth and Stock Prices: Evidence from Central and Eastern European Countries. Studia Prawno-Ekonomiczne, 179196.

[9] Gudaro, A., Chhapra, I., \& Sheikh, S. (2010). Impact of Foreign Direct Investment on Economic Growth: A Case Study of Pakistan. Journal of Management and.., 6 (2), 84-92. 
[10] Ishioro, BO (2013). Stock Market Development and Economic Growth: Evidence From Zimbabwe Developments in the Zimbabwe Stock Market, 343-360.

[11] Karagöl, E. (2002). The Causality Analysis of External Debt Service and GNP: The Case of Turkey.

[12] Kharusi, S. Al, \& Ada, MS (2018). External Debt and Economic Growth: The Case of Emerging Economy, 33 (1), 1141-1157.

[13] Masoud, NMH (2013). The Impact of Stock Market Performance on Economic Growth, 3 (4), 788-798.

[14] OECD. (2015). Foreign Direct Investments, (May s2013), 24-25. 